\title{
On the Gradient Implementation Path of College Students' Value Chain
}

\author{
Ming TANG \& Min WU \& Fang ZENG \\ Poyang Lake Eco-economy Research Enter in Jiujiang University, Jiangxi, China
}

\begin{abstract}
The realization of self-value for college students is an important manifestation for their campus life quality. It's very useful for college students to enhance their confidence in life,to understand themselves, perfect themselves, improve themselves and realize their self-value better. This paper divides college students' value chain into "three levels" and designs gradient implementation path of college students value chain by "five sections method" and to implement the starting point of time the detailed gradient, provide beneficial guidance for college students' campus life. And it specifies each starting point of value gradient implementation during the four years growing process in the university while providing beneficial guidance for college students' campus life.
\end{abstract}

KEYWORD: college students' value chain; implementation path; gradient

\section{INTRODUCTION}

College students have a strong thirst for knowledge and desire to show-off, also facing the actual pressure of changes in the growing social ability demand. It's of great significance to guide students to forming correct values. The necessity of college students' value realization is the basis and source of college campus behavior selection. Potter, in the research of enterprise "value chain" theory, pointed out that the competition between enterprises is not only a link, but also the competition between the whole value chain and the comprehensive competitiveness of the whole value chain determines the competitiveness of the enterprises. College students as individuals to participate in market competition directly, their competitiveness of size is also associated with the comprehensive competitiveness of the value chain. The gradient implementation path design of college students' value chain is very necessary for students to grow in the demand and implementation process.

Marx said, "when choosing a career, the main pointer we should follow is the happiness of mankind and our own perfection. We should not think that these two kinds of interests is hostile and conflict with each other."Here "human happiness" refers to the social value, "its own perfection" refers to the self-worth. College students' value chain system also includes the social value and selfworth .College students' social value is on the basis of college students' self-worth, while its social value promote its self-worth. Self-worth is basic premise and condition of social value, no self-worth, no social value.

\section{THE CHARACTERISTICS OF COLLEGE STUDENTS VALUE PREFERENCE}

\subsection{College students' value realization has strong subject consciousness.}

On the value orientation, College students don't consider their self value orientation in terms of their social contribution, or determine their self-worth which are not completely out of the social needs of the market with absolute ego orientation, but with the combination of both personal and social common development, however the basis point is college students' personal development[1].Starting from the pursuit of self feeling and fashionable personal life, college students' value orientation and emphasis on their own ability, with pragmatic view of society, their value preference advocates "ego" with strong subject consciousness.

\subsection{College students' self value orientation are multifarious.}

In the value relationship of college students, the value object is the stage of university campus life,which refers to a university of college students' 
learning process and a series of practical activities affected by the university life after graduation; The value of the subject is college students. The object of college students' value, on one hand must be able to meet the needs of the society, on the other hand, must try to meet the needs of the individual's allround development. So life value is a value system with multiple dimensions.

\subsection{College students' value is characterized by personality characteristics}

The pursuit of personality is the common psychological characteristics of contemporary college students. As the ways of knowledge and information acquisition are diversified, most college students refuse a mechanical and boring single way of education, while advocating participation in the education process as independent individuals, and making related evaluation; meanwhile they pursue independent observation, independent thinking, independent judgment, promoting diversified criterion, and respect social diversified interests[1].

\section{THE ANALYSIS OF THE CONNOTATION OF COLLEGE STUDENTS' VALUE CHAIN}

Maslow, as a famous American social psychologist, believes that a person's need of self-actualization is an desire for self-fulfillment, is also a kind of tendency to make the person to be able to realize his potential[2]. A man is a social person, has social attributes. No exception for college students who are also social and historical, objective and practical. The gradient implementation process of college students' value chain should be the unity of social value and self -value, which can be divided by "three levels" (Fig 1). The implementation of college students' value is that college students as object promote their full scale development of health, beauty, intelligence and physique, making themselves more perfect. Self-worth mainly includes one's usefulness, meeting one's own needs, which is a valuable relation under the condition of certain social individual self-awareness, self-improvement and self-development of social practice activities, the actual existence and implementation of his needs. The realization of the college students' social value is created by people's working for the society to provide high quality material value and the good value spiritual products, and realized by having a positive impact to society and promoting people's life. College students' social value is characterized by the valuable relationship between college students' individual behavior and other social groups' need, which has the utility to society by their personal life's meeting the needs of society.

\subsection{In the process of the realization of college students' gradient value chain, the realization of their own value is the foundation}

Self-worth is necessary for a college student to exist and develop as an individual. In an open environment and under the market economy system, college students' enhancing independence and subjectivity is the embodiment of the era as well as the needs of playing their enthusiasm and creativity. Specifically, the subjective conditions of college students to realize their value of life includes constantly improving their own ability, improving the abilities to realize their life value, making contributions based on reality and their own current work with an unyielding spirit, etc.. And a person is not isolated, he always exists as an individual in society, therefore the realization of the value of life also needs social conditions as that his behavior should be consistent with the system of socialist core values, and from the objective social conditions etc.

\subsection{The basic criterion of judging the gradient implementation effect of college students' value chain is based on the fact that whether the process of individual in the university is in line with the objective laws of development of society as a whole.}

The common standards that society judges a person's life value is from his contribution to society and others by working. Therefore, college students should pay special attention to their contribution to the society in the process of gradient implementation of value chain as the following: Firstly, they should do what students should do, fulfill their responsibilities conscientiously in their professional study, campus life and collective activities. Secondly, college students should focus on creating valuable life, the realization of value and the degree of its implementation has some important relation with how to treat the life environment in a certain environment. Thirdly, a college student should set up correct outlook on life and value in the process of gradient value chain realization. During many years' practical work as a headteacher, I have found that a lot of students have different psychological problems of different degree. This is because the undergraduates are in a specific psychological period, which is the internal cause of psychological problems; while the influence of social environment is the external causes of psychological problems. So it is the urgent needs of the reality for college students to adjust their own psychology and keeping their mental health consciously. Fourthly, students should adhere to honesty, tolerance, mutual aid, and correctly handle the relationship between competition and cooperation in the process of value chain's gradient implementation. The current social and economic development has provided college 
students with a broad stage to realize their life value, with a higher request for college students to create a valuable life. If college students want to realize their life value in a gradient and effective way, not only should they pay their attention to their own subjective conditions and improve their selfcultivation, also should pay more attention to their contribution to the collective.

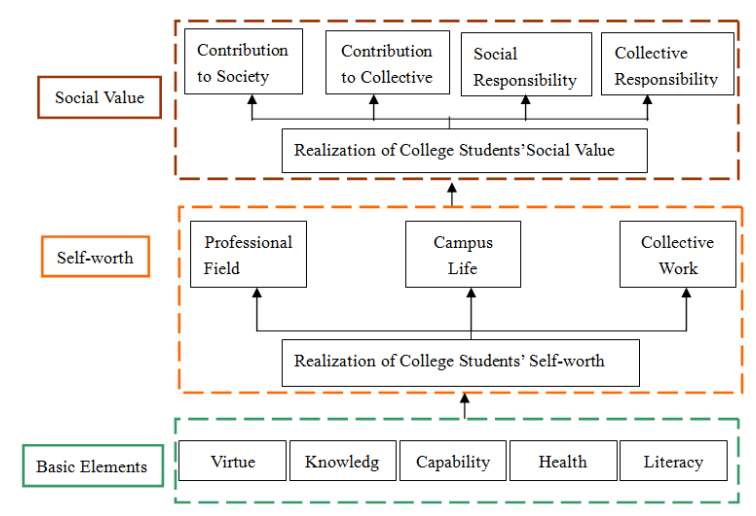

Fig 1. The sketch map of the "three level" connotation of college students' value chain

\section{THE DESIGN FOR THE GRADIENT REALIZATION PATH OF COLLEGE STUDENTS' SELF-WORTH}

Organize and execute the courses of action required to manage prospective situations." In other words, self-efficacy is a person's belief in his or her ability to succeed in a particular situation. Bandura described these beliefs as determinants of how people think, behave, and feel(1994). It has also been defined as a person's self-competence while accomplishing a task and the feeling of selfconfidence, self-respect and self-esteem. Mao zedong also believed that humanbeing's purpose is self-realization, which fully developed our physical and mental ability. College students improve the level of value-realization gradually from the cyclic process of "self discovery - fulfill potential showing capabilities - becoming successful continued perfection" (Fig 2).

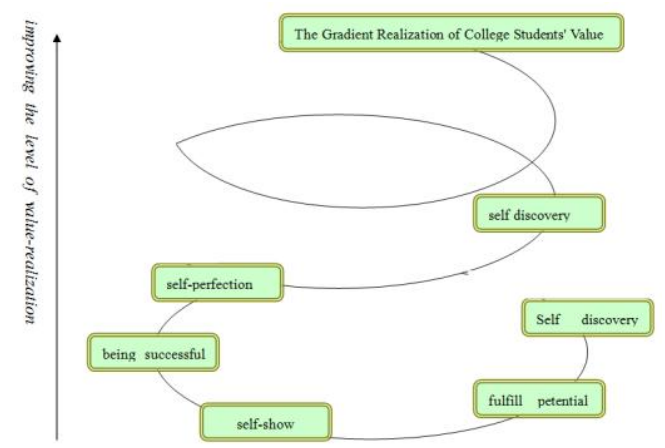

Fig 2. The "five period" design for the gradient realization path of college students' value chain

\subsection{College students'value self-orientation}

It mainly contains two aspects, namely, one is from its own perspective, to clear the direction, to set an achievable goal according to one's own power and interests; At the same time, to have a healthy mental state, have the courage to face and overcome setbacks. In addition, they must have firm faith, sense of responsibility and spirit of continuous innovation. Also, notice the pros and cons of the external environment. Starting from the first year of college entrance, through participating in the mental health test, from which try to tell whether the mentality of college students is right. At the same time, the entrance education activities and professional learning process and student activities organized by school can also help college students understand required professional qualtiy and employment prospects as soon as possible. From these content, they can gradually learn to find themselves and try to make good use of the potential advantages avoiding weaknesses.

\subsection{College students' self design value of value}

College students career planning, through the reasonable adjustment, combined with the actual, planning seriously and carefully a suitable way for their own development. Through social practice, professional practice, professional knowledge learning, and campus lectures, students can learn more about themselves, to provide a clear goal for the future, which is the foundation for college students to realize theirself value.

\subsection{College students' self assessment of value}

Self-assessment is the key link to explore potentialities, to show and improve themselves. Because they are evolving in the process, themselves will continue to improve, also new problems will appear, so it's necessary to set the stage for their evaluation regularly, in order to make proper adjustment when noticing something improper, to adapt to the growing and changing need of value realization. With the deepening of professional course learning and the change of market demand, it is also very necessary for college students to adjust appropriately the unattainable value link.

Take four-year undergraduate college life as an example, the process of gradient implementation of college students' value chain (Tab 1) are as the following : Freshman year, mainly in order to find their own real value to try, continuously learn to make self discovery in the process; Sophomore year, start thinking Syste maticly the plan and action in order to realize their own value; Grade three and grade four is the key to realize the college students' value chain, start with action to prove themselves, realize the value of their real life. The sophomore 
year the key is to find their real interest and excavate potential, thus making a choice and determine their own way to go for a long time after their graduation from college. So, the future goals will be established, and a reasonable plan will appear, which helps to realize the value of life.

The value of life is a concept of rich content, college students' value chain is an important part of the life value realization. College students' social value and self-value are interconnected, a dialectical unity, all of which is the result of college students' active creativity, is a kind of social evaluation of the purpose of life and behavior in college campus[3]. Correct understanding and evaluating the value of college students is an important condition of realizing one's life value and choose a right life path.

\section{ACKNOWLEDGEMENTS}

This research is a part of the project co-funded by Jiangxi province Education scientific planning
project(13YB142) and Jiujiang City soft science project(Research on the training mode of innovative talents in Jiujiang).

\section{REFERENCES}

[1] Gu Yuejuan, Jiang Qingyun. Innovation Countermeasures of College Students' Value Preference and Mass media, Journal of Hebei, 2013 (5): 188-190.

[2] Chenli, The Analysis of Maslow's Self-fulfillment Theory in the Application of Cultivating College Students' Healthy Personality, Heilongjiang Higher Education Research, 2008(4): 132-134.

[3] Zhao L, The LogicalPath of Value Realization of University Concept, journal of Beijing vocational college of politics and law, 2005 (2): 73-76.

[4] Bandura, A. (1994). Self-efficacy. In V. S. Ramachaudran (Ed.), Encyclopedia of human behavior, 4. New York: Academic Press, pp. 71-81.

Tab 1. The "five periods" design for the gradient realization path of college students' value chain

\begin{tabular}{|c|c|c|c|c|}
\hline $\begin{array}{l}\text { Periods of } \\
\text { gradient parth }\end{array}$ & $\begin{array}{l}\text { Completion } \\
\text { time }\end{array}$ & $\begin{array}{c}\text { Content of } \\
\text { gradient path }\end{array}$ & Design index & Index \\
\hline \multirow{3}{*}{ The first period } & \multirow{3}{*}{ Freshman year } & \multirow{3}{*}{ Self discovery } & learning & classroom learning; practical learning; self-learning \\
\hline & & & life & $\begin{array}{l}\text { self-management skill; campus life management; } \\
\text { participation family affairs }\end{array}$ \\
\hline & & & work & class activities; the second classroom; part-time job \\
\hline \multirow{3}{*}{$\begin{array}{l}\text { The second } \\
\text { period }\end{array}$} & \multirow{3}{*}{ Sophomore year } & \multirow{3}{*}{$\begin{array}{l}\text { Potentialities } \\
\text { exploitation }\end{array}$} & interests & $\begin{array}{l}\begin{array}{l}\text { language learning; professional } \\
\text { traditional cultural accomplishment; } \\
\text { chess, calligraphy and painting }\end{array} \\
\text { lyre-playing, }\end{array}$ \\
\hline & & & capabilities & $\begin{array}{l}\text { logical thinking; spatial imagination; Systemic } \\
\text { Thinkin; Innovation and entrepreneurship; } \\
\text { coordinate organization; communication skills }\end{array}$ \\
\hline & & & skills & $\begin{array}{l}\text { Professional practice process; Information network } \\
\text { development; cutivation of comprehensive skills }\end{array}$ \\
\hline \multirow{3}{*}{ The third period } & \multirow{3}{*}{ Junior year } & \multirow{3}{*}{ Show oneself } & $\begin{array}{l}\text { classroom } \\
\text { learning }\end{array}$ & subject test; group discussion activities; big tasks \\
\hline & & & $\begin{array}{l}\text { Extracurricul } \\
\text { ar activities }\end{array}$ & $\begin{array}{l}\text { League activity; Youth volunteer activities; class } \\
\text { activities; to participate in the activities of schools }\end{array}$ \\
\hline & & & $\begin{array}{c}\text { Social } \\
\text { practice }\end{array}$ & $\begin{array}{ccc}\text { professional practice teaching; } & \text { social } \\
\text { investigation; part-time job } & & \\
\end{array}$ \\
\hline \multirow{3}{*}{$\begin{array}{l}\text { The fourth } \\
\text { period }\end{array}$} & \multirow{3}{*}{ Senior year } & \multirow{3}{*}{ Be successful } & learning & $\begin{array}{l}\text { further study ; academic } \text { achievements; } \\
\text { Qualification for professional job; literary } \\
\text { accomplishment; synthetic knowledge system }\end{array}$ \\
\hline & & & life & $\begin{array}{l}\text { Personal life management; Personal relationship } \\
\text { problems; Relationship between teachers and students }\end{array}$ \\
\hline & & & work & $\begin{array}{l}\text { Career plan; Vocational choice; jobs; Social } \\
\text { contribution and responsibility }\end{array}$ \\
\hline The fifith period & $\begin{array}{l}\text { The four-year } \\
\text { period }\end{array}$ & Self perfection & \multicolumn{2}{|c|}{$\begin{array}{l}\text { From the above aspects, and in view of the above four stages, make } \\
\text { scientific evaluation, perfect oneself. }\end{array}$} \\
\hline
\end{tabular}

